\title{
The Impact Of Outside Director Equity Compensation On Dividend Policy
}

\author{
Guy McClain, Ph.D., Auburn University, USA and IESEG School of Management, France
}

\begin{abstract}
This study investigates the impact outside director equity compensation has on dividend policy. The analysis, conducted over a 4 year period from 1997-2000, is based on a sample of 89 first time adopters of equity compensation. The use of first time adopters attempts to control for the fact that many of the variables in the study are endogenously determined over time. The results indicate that as the percentage of equity compensation increases a firm's propensity to pay dividends decreases as does the level of dividends. These results also indicate that firms with higher profitability pay a lower level of dividends. Taken together these result indicate that as managers send signals about positive performance, outside directors with a financial stake in the company decrease the level of monitoring by paying fewer dividends.
\end{abstract}

Keywords: Outside Director Equity Compensation; Dividend Policy

\section{INTRODUCTION}

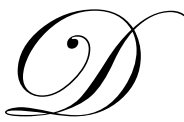

ividend policy, according to agency theory, is developed by the separation of ownership and control between managers and shareholders (Jensen 1986). Due to agency costs, managers may not always choose a dividend policy that is in the best interest of shareholders. Rather, they may choose a dividend policy that maximizes their own private benefits. Dividend payouts are argued to reduce agency problems by exposing managers to increased scrutiny by capital markets, as paying dividends increases the need for additional capital (Easterbrook 1984). In addition, dividends reduce the amount free-cash flows available to managers which could be used for their private benefits rather than shareholder maximization (Jensen 1986).

While previous literature has focused on the relationship between dividend payouts and firm-level economic indicators like agency costs (Rozeff 1982; Alli et al. 1993; Zeng 2003), transaction costs (Alli et al . 1993; Zeng 2003), tax considerations (Alli et al. 1993; Zeng 2003) and managerial considerations (Alli et al. 1993; Baker and Powell 2000; Zeng 2003) few studies, however, have investigated the role boards of directors' play in the decision to pay dividends. Boards of directors are one part of a firm's governance structure that allocates the rights of control over the firm's assets (Hart 1995). That is, boards of directors have the responsibility to oversee or decide how those assets (in this case excess cash) are used.

Schellenger et al. (1989) found that the percentage of outside versus inside directors is positively associated with dividend payouts. Farinha (2003) found that dividend payouts are positively associated with Cadbury ${ }^{1}$ compliance in UK firms. Although those studies provide evidence that outside director composition influences corporate dividend policy, a comparison between outside director compensation and dividend policy has not been studied. The need for this information would benefit governance scholars and activists as outside director compensation is scrutinized more in the financial press (Iwata 2007).

\footnotetext{
${ }^{1}$ The Cadbury Report titled Financial Aspects of Corporate Governance, is a nineteen-item code of best practices for corporate boards and accounting systems issued by a joint committee of the London Stock Exchange, the Financial Reporting Council and the accountancy profession in the United Kingdom.
} 
The purpose of this paper, therefore, is to investigate the impact the mix of outside director equity ${ }^{2}$ compensation has on corporate dividend payout ratio. To the extent outside directors' independence or willingness to monitor management is impaired, secondary or cascading agency costs develop between outside directors and shareholders. To combat secondary agency costs, equity compensation has been suggested as the preferred mechanism to align outside directors with shareholders since it gives the outside director a direct financial stake in the company (Elson 1995; Jensen 1993). Some scholars, however, argue that the direct financial interest created by the equity compensation actually creates a series of conflicts between the director and shareholder (Dalton and Daily 2001). Therefore, the purpose of this paper is to answer the question: how does outside director equity compensation affect the dividend policy of firms?

To answer this question I use a sample of 89 firms in the initial year of their outside director equity compensation plan from the period 1997-2000. Using a sample of firms in the first year of plan adoption decreases the sample size, but allows for a clearer delineation of the effect outside director compensation has on dividend policy by reducing endogeneity. Models that do not take this into account may confound interpretation of resulting coefficients. Lagging variables helps, but within panel data and cross-sectional data there is no guarantee that the lagged variable is lagged far enough to capture the initial difference in dividend policy. By using a sample of firms in their first year of outside director equity compensation the model attempts to control for this effect.

Results suggest that to the higher the percentage of outside director equity compensation the less likely a firm is to pay a dividend and if paid, the lower the dividend payout. It should be noted, however, that the dividend payout seems to be moderated by the firm's profitability. That is, to the extent managers are able to send positive signals about their ability through higher profitability measures, the fewer dividends outside directors approve to be paid.

The next section discusses the literature review and develops the research question. Section 3 describes the research design and data. Section 4 provides the empirical results and the paper is concluded in section 5.

\section{PREVIOUS LITERATURE AND RESEARCH QUESTION DEVELOPMENT}

\subsection{Dividend Policy}

Rozeff (1982) was the first to introduce agency costs as a potential explanation for dividend policy. Rozeff, using a model that proxies for both agency costs and investment policy, documented a negative association between dividend policy and agency costs. He reasoned that managers wanted to reduce the cash distributed to shareholders (i.e., retain more cash in the firm) in order to avoid costly external financing. Building on that study, Easterbrook (1984) theorized that dividends play a role in controlling agency costs within a firm by increasing the likelihood that funds are raised externally. External capital is not only costly, but causes increased managerial scrutiny by the providers of that capital (i.e., investment bankers, securities exchanges, regulatory agencies). Hansen and Torregrosa (1992) document that managerial avoidance of monitoring is publicly observed by financial analysts and thus subjects managers to potentially greater penalties than those that might be the result of investment banker monitoring. Additionally, Jensen (1986) theorized that dividends are used to reduce the availability of freecash flows to managers. Thus, reduction in discretionary funds through increased dividends minimizes the risk of managerial investment in projects that do not increase shareholder value.

\subsection{Outside Director Compensation}

Outside director equity compensation is used to increase the alignment between outside directors and shareholders by giving the outside director a direct financial interest in the performance of the firm. This direct financial stake should create incentives for the outside director to actively monitor management (Elson 1995; Jensen 1993). For example, outside director equity holdings have been found to be positively associated with the resistance of greenmail (Kosnik 1987), while negatively associated with the likelihood of hostile takeovers (Shivdasani 1993)

\footnotetext{
${ }^{2}$ Equity compensation, for outside directors, is typically stock issues that are put in a trust that the director does not have access to until retirement. Thus, the equity compensation effectively acts likes an option.
} 
and financial statement fraud (Beasley 1996). Dividend policy, therefore, is another mechanism at the disposal of outside directors by which they can monitor management.

Not all governance scholars, however, agree with the agency perspective of outside director equity compensation. Opponents (e.g. Kaback 1996; Dalton and Daily 2001) cite numerous theoretical problems with outside director equity compensation. For example, equity compensation produces negative cash flow for the outside director since it produces taxable income without cash flow (Kaback 1996). Equity compensation may influence outside directors to approve stock buybacks, stock option resets, and stock reloads (Dalton and Daily 2001), which may or may not be in the shareholders' best interest. Additionally, outside directors may focus on short-term time horizons, if they are overly concerned with their present wealth instead of long-term wealth effects (Daily and Dalton 2002). Perhaps more compelling is the idea that compensating outside directors with equity treats them as if they were an employee. Outside directors are normally a professional body of business experts elected by shareholders to provide independent oversight of management. Other professional bodies that require a level of independence are either prohibited or dissuaded from holding any financial interest in a client. For example, the Public Company Accounting Oversight Board deems an auditor as not independent if any member of the firm has any financial interest in an audit client (Kaback 1996; Dalton and Daily 2001).

In addition, equity compensation rewards stock price appreciation (Murphy 1999). Dividends reduce the value of the option which entices managers to reduce dividends. Lambert et al. (1989) found evidence that dividend payout ratios decrease relative to expected levels after the adoption of an executive stock option plan. Lewellen et al. (1987) found that dividend payout ratios are negatively, and significant, associated with executive stock-option compensation. Directors with stock options, therefore, may have incentives to reduce dividends in order to increase the value of their equity holdings.

Therefore, my research question is as follows:

Research Question: How does the inclusion of outside director equity compensation impact a firm's dividend policy?

\section{RESEARCH DESIGN}

\subsection{Empirical Specification}

I use a propensity to pay dividends similar to Fama and French (2001) to investigate the relation between outside director equity compensation and dividends. This model has been used in other governance papers that investigate dividends (see Price et al. 2011). The dependent variable, the propensity to pay dividends (PPD), is equal to one if a dividend is paid and zero otherwise. Similar to Price et al. (2011) I also use dividend payout ratio (DPR), as another dependent variable. It is calculated as the dividends paid divided by net income.

Mix of equity (MOE) is the dollar amount of equity compensation divided by the total dollar value of all compensation. Compensation data was collected from firm proxy statements (form DEF 14A) filed with the SEC's Edgar Database. Total compensation is calculated as the total dollar amount of cash retainers, cash meeting fees and all stock-based compensation as valued by the Black-Scholes (1973) model. Similar to Certo et al. (2008), I assume options are awarded at the money (exercise price equal to market price on the day of the option grant which is assumed to be the price at the end of the most recent fiscal year end) and time to maturity is ten years.

Based on the evidence provided by Fama and French (2001), three fundamentals are factors in the decision to pay dividends: profitability, size and investment opportunities. To measure firm profitability I use return on assets $\left(\mathrm{ROA}_{t}\right)$ and to measure size I use the market value of equity $\left(\mathrm{MVE}_{\mathrm{t}-1}\right) . \mathrm{ROA}_{\mathrm{t}}$ is the natural log of one plus net income before extraordinary items plus interest expense divided by the beginning total asset. $\mathrm{MVE}_{\mathrm{t}-1}$ is the natural $\log$ of the market value of equity as of the end of year t-1. I would expect firms that pay dividends to be larger and more profitable (Fama and Jensen 2001; Price et al. 2011). Alternatively, more profitable firms may be evidence that agency problems are not significant and dividends may be reduced to give the manager more discretion on how to invest funds (Farinha 2003). In addition, a firm's size increases its agency problems increase, but from another perspective, firm size decreases the transaction costs associated with external financing (Farinha 2003). 
To measure investment opportunities $\mathrm{I}$ use the book value of equity $\left(\mathrm{BVE}_{\mathrm{t}-1}\right)$ to capture growth opportunities and sales growth $\left(\mathrm{SG}_{\mathrm{t}}\right)$ to capture realized growth. The $\mathrm{BVE}_{\mathrm{t}-1}$ is the natural log of one plus the book value of equity divided by the market value of equity as of the end of the year $t-1 . S_{t}$ is the natural $\log$ of one plus the annual change in sales between year $\mathrm{t}-1$ and $\mathrm{t}$ divided by year $\mathrm{t}-1$ sales. I would expect firms with higher investment opportunities to be less likely to pay dividends (Fama and French 2001).

To examine whether outside director compensation influences dividend policy, I test the association between mix of equity compensation and the propensity to pay dividends and the dividend payout ratio. To test the propensity to pay dividends I use a logistic regression model and to test the dividend payout ratio I use an OLS regression. In both models the dividend variables are the dependent variables, mix of equity is the test variable and measures of profitability, size and investment opportunities are the major independent variables. The empirical model used is as follows:

$$
\mathrm{DEP}_{\mathrm{k}, \mathrm{t}}=\beta_{0}+\beta_{1} \mathrm{ROA}_{\mathrm{k}, \mathrm{t}}+\beta_{2} \mathrm{MVE}_{\mathrm{k}, \mathrm{t}-1}+\beta_{3} \mathrm{BVE}_{\mathrm{k}, \mathrm{t}-1}+\beta_{4} \mathrm{SG}_{\mathrm{k}, \mathrm{t}-1}+\beta_{5} \mathrm{MOE}_{\mathrm{k}, \mathrm{t}}+\text { error }_{\mathrm{k}, \mathrm{t}}
$$

Where $\mathrm{k}$ indicates the firms and $\mathrm{t}$ indicates the year;

$\mathrm{DEP}_{\mathrm{k}, \mathrm{t}}=$ one of two variables: the propensity to pay dividends (PPD) equal to one if a dividend is paid and zero otherwise; or the dividend payout ratio (DPR), calculated as dividends paid divided by net income
$\mathrm{ROA}_{\mathrm{k}, \mathrm{t}}=$ return on assets, calculated as the natural log of one plus net income before extraordinary items plus interest expense divided by the beginning total asset
$\mathrm{MVE}_{\mathrm{k}, \mathrm{t}-1}=$ the natural $\log$ of the market value of equity as of the end of year $\mathrm{t}-1$
$\mathrm{BVE}_{\mathrm{k}, \mathrm{t}}=$ the natural log of one plus the book value of equity divided by the market value of equity as of the end of the year $\mathrm{t}-1$

$\mathrm{SG}_{\mathrm{k}, \mathrm{t}-1}=\quad \begin{aligned} & \text { the natural } \log \text { of one plus the annual change in sales between year } \mathrm{t}-1 \text { and } \mathrm{t} \text { divided by year } \mathrm{t}-1 \\ & \text { sales }\end{aligned}$

$\mathrm{MOE}_{\mathrm{k}, \mathrm{t}}=$ the mix of equity, calculated as the dollar value of equity divided by the dollar value of total compensation

\subsection{Sample and Data}

The sample of firms used to investigate the association between outside director compensation mix and dividend policy was done in multiple stages. First, firms in their initial year of an outside director equity compensation policy were identified by querying Standard \& Poor's ExecuComp database for all outside directors who received zero stock grants or stock options in 1997, 1998, 1999, and 2000. This search resulted in 734 firms. Because this study investigates the adoption of a governance reform, such as the decision to pay dividends, 415 firms were excluded that operate in an industry with government regulation which acts as an additional layer of monitoring. An industry is considered to have government regulation if it is a financial services firm or a utility. Next, individual queries on each of the remaining 319 firms were performed to identify the first year in which outside directors received either stock grants or stock options. One hundred eighty seven firms were eliminated in which equity compensation has been used in previous years.

Of the 132 remaining firms, 16 firms were eliminated because financial information was not available and 27 were eliminated because they did not have 5 years of additional financial information beyond the plan adoption date due to either mergers/ acquisitions (23) or delisting of trading securities (4). Thus, there is a final sample of 89.

Once a firm was identified as feasible and plan adoption date found, financial variables are obtained from Compustat while market related data is obtained from CRSP. Board of director variables such as compensation and 
composition are collected from firm proxy statements filed on the Securities and Exchange Commission's EDGAR database. Table 1 presents the distribution of the sample firms by industry and year.

Table 1

Distribution of sample firms by year of equity plan adoption and Standard Industry Code (SIC)

Panel A: The distribution by year of equity plan adoption

Year of equity plan adoption
1997
1998
1999
2000

Year of equity plan adoption

1998

2000

Number of firms in sample
9

25

26
tal
$\underline{29}$

Panel B: The distribution by SIC

SIC
1
2
3
4
5
7

\begin{tabular}{c} 
Firms in sample \\
6 \\
16 \\
27 \\
6 \\
12 \\
$\underline{22}$ \\
\hline 9
\end{tabular}

\section{RESULTS}

\subsection{Descriptive Statistics}

Summary statistics on outside board of director compensation are presented in Table 2. On average outside boards of directors receive average (median) total compensation of $\$ 121,414(\$ 62,544)$, with a range of $\$ 2,217,520$ to $\$ 13,392$. Total compensation is comprised of average (median) cash compensation of $\$ 26,768(\$ 27,000)$. Cash compensation is comprised of an average (median) cash retainer of $\$ 19,548(\$ 20,000)$ and an average (median) per meeting fee of $\$ 1,079(\$ 1,000)$. The average number of meetings was 6.69 with average (median) cash from meetings of $\$ 7,220(\$ 6,000)$. The lowest cash compensation was zero, while the highest was $\$ 70,000$. The average (median) value of equity compensation was $\$ 94,646(\$ 28,544)$ with a high of $\$ 2,217,520$ and a low of $\$ 3,392$.

Table 2

Descriptive statistics of director compensation in the year of the plan adoption $(n=89)$

\begin{tabular}{|c|c|c|c|c|c|}
\hline & Mean & Median & Maximum & Minimum & Standard Deviation \\
\hline \multicolumn{6}{|l|}{ Cash Compensation } \\
\hline Annual cash retainer & $\$ 19,548$ & $\$ 20,000$ & $\$ 55,000$ & $\$ 0$ & $\$ 13,578$ \\
\hline Fee per meeting & $\$ 1,079$ & $\$ 1,000$ & $\$ 5,000$ & $\$ 0$ & $\$ 948$ \\
\hline Number of meetings & 6.69 & 6 & 18 & 2 & 2.87 \\
\hline Cash from meetings & $\$ 7,220$ & $\$ 6,000$ & $\$ 20,000$ & $\$ 0$ & $\$ 5,327$ \\
\hline Total cash compensation & $\$ 26,768$ & $\$ 27,000$ & $\$ 70,000$ & $\$ 0$ & $\$ 14,946$ \\
\hline \multicolumn{6}{|l|}{ Equity Compensation } \\
\hline Value of stock grants & $\$ 94,646$ & $\$ 28,544$ & $\$ 2,217,520$ & $\$ 3,392$ & $\$ 249,665$ \\
\hline Total compensation & $\$ 121,414$ & $\$ 62,544$ & $\$ 2,217,520$ & $\$ 13,392$ & $\$ 247,154$ \\
\hline
\end{tabular}

Table 3 presents descriptive statistics for the dependent variables, the measures of profitability, size, investment opportunities and mix of equity. The mean (median) propensity to pay dividends and the dividend payout ratio is 1 (1) and 0.177 (0.094), respectively. Firms on average (median) had return on assets of 0.081 (0.075), market value of equity of 7.226 (7.075), book value of equity of $0.401(0.383)$ and sales growth of 0.113 (0.072). Equity compensation was on average (median) 0.554 (0.539) of outside director compensation packages. 


\subsection{Univariate Analysis}

Table 4 presents correlations among the dependent variables, measures of profitability, size, investment opportunities and the mix of equity. The propensity to pay dividends and the dividend payout ratio are both positively (negatively) correlated with the market value of equity (sales growth and mix of equity). Return on assets is positively correlated with sales growth and negatively correlated with the book value of equity. The market value of equity is negatively correlated with the book value of equity, the book value of equity is negatively correlated with sales growth. In addition, the mix of equity is positively correlated with sales growth. To further test these relationships, multivariate analyses are performed.

Table 3

Summary statistics of all variables at the time of equity plan adoption $(\mathbf{n}=\mathbf{8 9})$

\begin{tabular}{cccccc}
\hline Variables & Mean & Median & Maximum & Minimum & Standard Deviation \\
\hline PPD & 0.600 & 1 & 1 & 0 & 0.494 \\
DPR & 0.177 & 0.094 & 1.299 & 0 & 0.241 \\
ROA & 0.081 & 0.075 & 0.233 & .005 & 0.0455 \\
MVE & 7.226 & 7.075 & 11.877 & 3.517 & 1.471 \\
BVE & 0.401 & 0.383 & 0.914 & 0.061 & 0.206 \\
SG & 0.113 & 0.072 & 1.126 & -1.100 & 0.283 \\
MOE & 0.554 & 0.539 & .0588 & 0.277 \\
\hline
\end{tabular}

Variable definitions

PPD is the propensity to pay dividends, equal to one if a dividend is paid and zero otherwise; or the dividend payout ratio DPR is the dividend payout ratio, , calculated as dividends paid divided by net income

ROA is the return on assets, calculated as the natural log of one plus net income before extraordinary items plus interest expense divided by the beginning total asset

MVE is the natural log of the market value of equity as of the end of year $\mathrm{t}-1$

BVE is the natural log of one plus the book value of equity divided by the market value of equity as of the end of the year $t-1$

$\mathrm{SG}$ is sales growth calculated as the natural log of one plus the annual change in sales between year $\mathrm{t}-1$ and $\mathrm{t}$ divided by year $\mathrm{t}-1$ sales

MOE is the mix of equity, calculated as the dollar value of equity divided by the dollar value of total compensation

\subsection{Multivariate Analyses}

Table 5 presents the results of the regressions of my empirical models. Panel A estimates the propensity to pay dividends using a logit model by examining variables proxying for the profitability, size, investment opportunities and mix of outside director equity compensation. The model is significant using a Chi-square test at a value less than 0.001 and has an pseudo $R^{2}$ of 0.362 (similar to Price et al. 2011), suggesting that the variables identified in this study are important in determining the propensity to pay dividends.

Consistent with the findings of Fama and French (2001) and Price et al. (2011), the results suggest that the propensity to pay dividends is positively related to firm profitability $\left(\mathrm{ROA}_{t}\right)$ and size $\left(\mathrm{MVE}_{\mathrm{t}-1}\right)$, while at the same time, is negatively related realized growth $\left(\mathrm{SG}_{\mathrm{t}-1}\right)$. The results suggest that larger more profitable firms, with less growth opportunities, are more likely to pay dividends. The significantly negative coefficient on the mix of equity $\left(\mathrm{MOE}_{\mathrm{t}}\right)$ suggests that as outside directors receive a higher percentage of equity compensation those firms are less likely to pay dividends.

Table 4

Pearson correlations between the variables used in the regressions

\begin{tabular}{|c|c|c|c|c|c|c|c|c|}
\hline & Variable & 1 & 2 & 3 & 4 & 5 & 6 & 7 \\
\hline 1 & PPD & 1 & & & & & & \\
\hline 2 & DPR & $0.613 * *$ & 1 & & & & & \\
\hline 3 & ROA & 0.176 & -0.166 & 1 & & & & \\
\hline 4 & MVE & $0.292 * *$ & $0.247 *$ & 0.032 & 1 & & & \\
\hline 5 & BVE & -0.074 & 0.115 & $-0.451 * *$ & $-0.459 * *$ & 1 & & \\
\hline 6 & SG & $-0.335 * *$ & $-0.292 * *$ & $0.282 * *$ & -0.016 & $-0.264 *$ & 1 & \\
\hline 7 & MOE & $-0.424 * *$ & $-0.411 * *$ & 0.39 & -0.091 & -0.179 & $0.391 * *$ & 1 \\
\hline
\end{tabular}


Panel B of table 5 presents the OLS regression on the association between dividend payout and the mix of outside director equity compensation on a subset of firms from the sample that pay dividends. The model has an $\mathrm{F}$ test significant at a $p<0.001$ and has an $\mathrm{R}^{2}$ of 0.255 , suggesting that the variables in included in the model are important in explaining dividend payout. The results indicate that dividend payout has a negative relationship with return on assets $\left(\mathrm{ROA}_{\mathrm{t}}\right.$ ) and a negative relationship with market value of equity $\left(\mathrm{MVE}_{\mathrm{t}-1}\right)$ and the mix of outside director equity compensation $\left(\mathrm{MOE}_{\mathrm{t}}\right)$. These results suggest that in firms that do pay dividends the firms that are more profitable pay less dividends and fewer dividends are paid as the percentage of outside director equity compensation increases.

\section{CONCLUSION}

The board of directors is elected to monitor management. One way in which directors potentially monitor management is through the payments of dividends which would reduce the amount of cash at the manager's disposal. Citing cases of ineffective outside director monitoring, numerous scholars (for example Jensen 1993; Elson 1995) have proposed that outside directors be compensated with equity as to align them with shareholders by giving them a direct financial stake. This paper directly tests the role outside director equity compensation has on the propensity to pay dividends and the level of dividends paid.

Table 5

Results of regressions on the association between the mix of outside director equity compensation and dividends

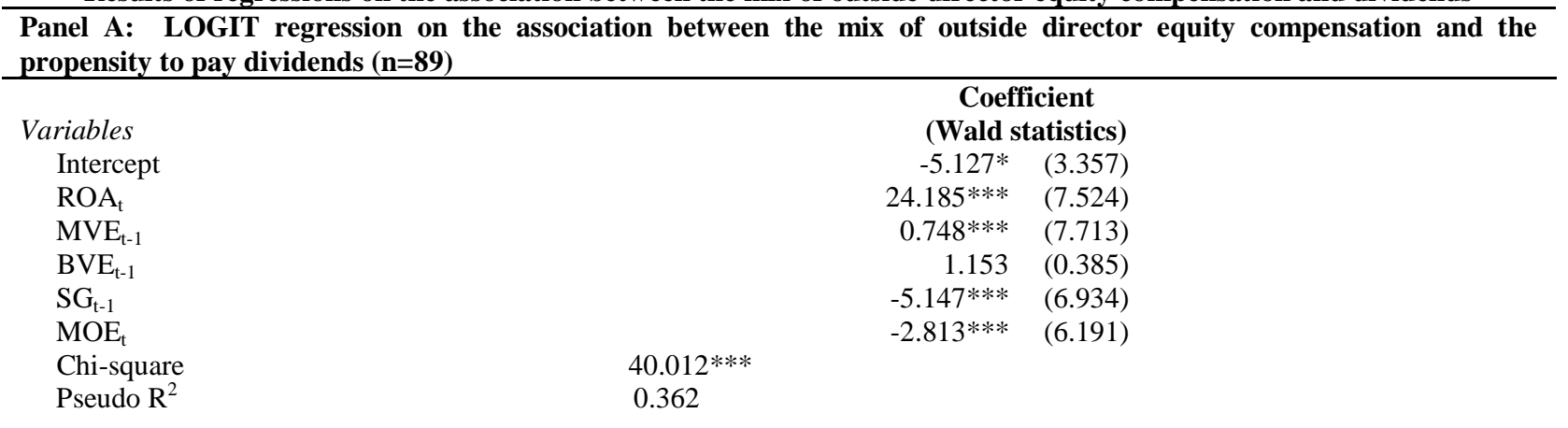

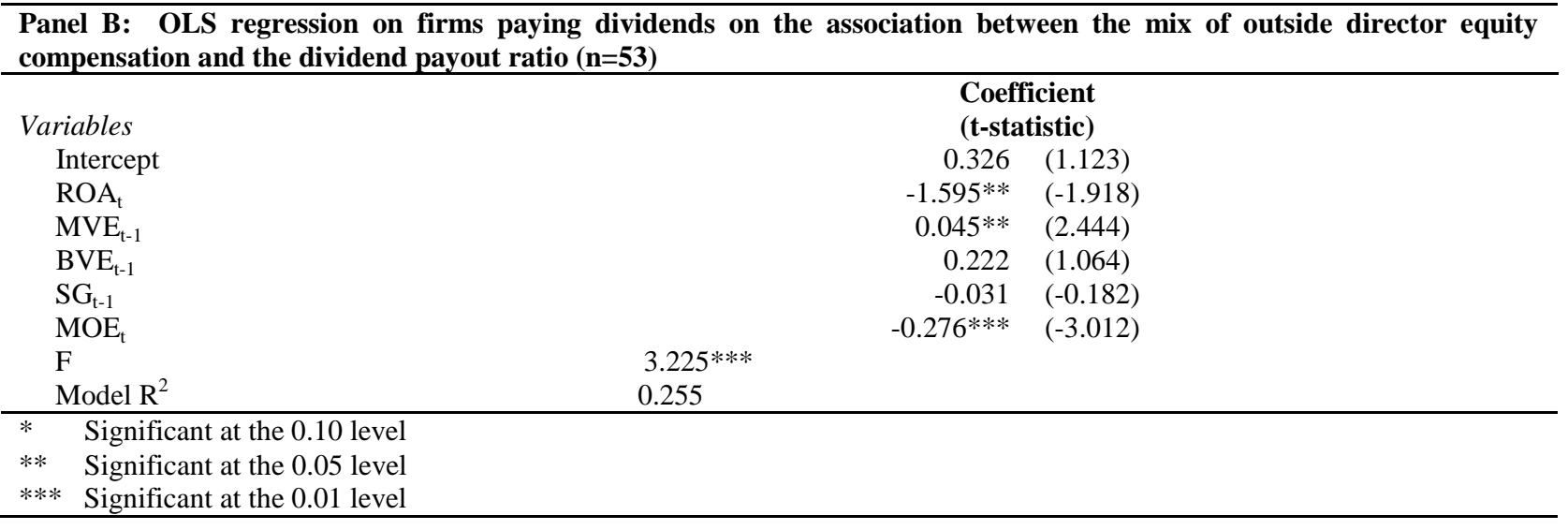

My analysis is conducted on a sample from 1997 to 2000 and was applied to 89 firms that are first time users of equity in their outside director compensation plans. My first regression model uses logit to test the association between the mix of outside director compensation and the propensity to pay dividends. The findings suggest that as the percentage of equity increases firms are less likely to pay dividends. The results also suggest that more profitable firms are more likely to pay dividends. So, to the extent firm profitability sends positive signals about a manger's ability, outside directors who have a higher percentage of equity compensation (whom are 
presumed to be actively monitoring because of this financial stake) are less likely to pay dividends. In other words, the manager has proven herself, so additional monitoring is not needed.

The second regression uses a subsample of my sample firms to include only those firms that pay dividends. Using OLS regression the results suggest that as the percentage of equity increases the dividend payout decreases. Also, return on assets is also negatively associated with dividend payout. These results tell a similar story as the results from the previous regression. That is, in firms that do pay dividends managers who send strong signals about ability (i.e., higher profitability) require less monitoring.

Any generalization of these results to other firms should proceed with caution. First, the sample size is small as compared to other studies of this type. While the 89 firms were selected with specific criteria in mind (i.e., initial year of an outside director equity compensation plan), the results' applicability to all firms is not suggested. Additionally, the data is from 1997 to 2000. Sarbanes Oxley has changed the corporate governance environment, including the ability of firms to select and retain outside directors because of perceptions of greater legal liability. Increased legal exposure has had an effect of outside director compensation and the manner in which outside directors monitor executive management.

\section{AUTHOR INFORMATION}

Guy McClain is an assistant professor of accounting at Auburn University and an Affiliated Professor at the IESEG School of Management in Lille, France. His main research interests are corporate governance, compensation and financial reporting/disclosure. E-mail: gmm0003@auburn.edu

\section{REFERENCES}

1. Alli, Kasim L; Khan, A. Qayyum and Gabriel G. Ramirez. 1993. Determinants of corporate dividend policy: a factorial analysis. The Financial Review. Vol. 28, No. 4, pp. 523- 547.

2. Baker, H. Kent and Gary E. Powell. 2000. Determinants of corporate dividend policy: a survey of NYSE firms. Financial Practice and Education. Vol. 10 No. 1, pp. 29- 20.

3. Beasley, Mark S. 1996. An empirical analysis of the relation between the board of director composition and financial statement fraud. Accounting Review. Vol. 71, No. 4, pp. 443- 465.

4. Black, Fischer and Myron Scholes. 1973. The pricing of options and corporate liabilities. Journal of Political Economy. Vol. 81, No. 3, pp. 637-654.

5. Certo, S., Dalton C., Dalton D. \& Lester R., 2008. Boards of directors' self interest: expanding pay in corporate acquisitions? Journal of Business Ethics, Vol. 77, No. 2, pp. 219-230, 2008.

6. Daily, Catherine M. and Dan R. Dalton. 2002. The problem with equity compensation. The Journal of Business Strategy. Vol. 23, No. 4, pp. 28-30.

7. Dalton, Dan and Catherine Daily. 2001. Director stock compensation: an invitation to a conspicuous conflict of interest? Business Ethics Quarterly. Vol. 11, No. 1, pp. 89-108.

8. Easterbrook, Frank H. 1984. Two agency-cost explanations of dividends. American Economic Review. Vol. 74, No. 4, pp. 650- 659.

9. Elson, Charles M. 1995. The duty of care, compensation, and stock ownership. University of Cincinnati Law Review. Vol. 63, No. 2, pp. 649-711.

10. Fama, Eugene F. and Kenneth R. French. 2001. Disappearing dividends: changing firm characteristics or lower propensity to pay. Journal of Financial Economics. Vol. 60, No. 1, pp.3-43

11. Farinha, Jorge. 2003. Dividend policy, corporate governance and the managerial entrenchment hypothesis: an empirical analysis. Journal of Business Finance \& Accounting Vol. 30, No. 9, pp. 1173- 1209.

12. Hansen, Robert S. and Paul Torregrosa. 1992. Underwriter compensation and corporate monitoring. Journal of Finance. Vol. 47, No. 4, pp. 1537- 1556.

13. Hart, Oliver. 1995. Corporate governance: some theory and implications. The Economic Journal. Vol. 105, No. 430, pp. 678- 689.

14. Iwata, Edward. 2007. Company directors' average pay passes $\$ 160,000$; compensation up $12 \%$ in '06. USA Today. January 31. 
15. Jensen, Michael C. 1993. The modern industrial revolution, exit, and the failure of internal control systems. Journal of Finance. Vol. 48, No. 3, pp. 831-880.

16. Jensen, Micheal C. 1986. Agency costs of free cash flows, corporate finance, and takeovers. American Economic Review. Vol. 76, No. 2, pp. 323- 329.

17. Kaback, Hoffer. 1996. The case for cash for directors. Directors \& Boards. Vol. 20, No. 2, pp. 14-24.

18. Kosnik, Rita D. 1987. Greenmail: a study of board performance in corporate governance. Administrative Science Quarterly. Vol. 32, No. 2, pp. 163-185.

19. Lambert, Richard A.; Lanen, William N. and David F. Larker. 1989. Executive stock option plans and corporate dividend policy. Journal of Financial and Quantitative Analysis. Vol. 24, No 4, pp. 409- 425.

20. Lewellen, Wilbur; Loderer, Claudio and Kenneth Martin. 1987. Executive compensation and executive incentive problems. Journal of Accounting and Economics. Vol. 9, No. 3, pp. 287- 310.

21. Murphy, Kevin J. 1999. Executive compensation. Handbook of Labor Economics. Edited by Orley Ashenfelter and David Cards. Vol. 3. North Holland: Elsevier Science.

22. Price, R., Romàn F. \& Rountree B. 2011. The impact of governance reform on performance and transparency. Journal of Financial Economics. Vol. 99, pp. 76-96.

23. Rozeff, Michael S. 1982. Growth, beta and agency costs as determinants of dividend payout ratios. The Journal of Financial Research. Vol. 5, No. 3, pp. 249- 259.

24. Schellenger, Michael H.; Wood, David A. and Ahmad Tashakori. 1989. Board of director composition, shareholder wealth, and dividend policy. Journal of Management. Vol. 15, No. 3, pp. 457- 467.

25. Shivdasani, Anil. 1993. Board composition, ownership structure, and hostile takeover. Journal of Accounting and Economics. Vol. 16, Nos. 1-3, pp. 167-198.

26. Zeng, Tao. 2003. What determines dividend policy: a comprehensive test? Journal of American Academy of Business. Vol. 2, No. 2, pp. 304- 309. 


\section{NOTES}

